\title{
4E Analysis of a Fuel Cell and Gas Turbine Hybrid Energy System
}

\author{
Nima Norouzi 1 ,*iD \\ 1 Department of Energy Engineering and Physics, Amirkabir University of Technology (Tehran Polytechnic), 424 Hafez \\ Avenue, PO. Box 15875-4413, Tehran, Iran \\ * Correspondence: nima1376@aut.ac.ir;
}

Scopus Author ID 57213160563

Received: 15.05.2020; Revised: 14.06.2020; Accepted: 15.06.2020; Published: 18.06.2020

\begin{abstract}
Exergy analysis of the expansion turbine hybrid cycle of integrated molten carbonate fuel cells is presented in this study. The proposed cycle was used as a sustainable energy curriculum to provide a small hybrid power plant with high energy efficiency. To generate electricity with the system mentioned above, and externally repaired fusion carbon fuel cell was used located at the top of the combined cycle. Moreover, the turbine and steam turbine systems are considered as complementary and bottom layers for co-generation, respectively. The results showed that the proposed system could reach net energy of up to 1125 kilowatts, while the total exergy efficiency (including electricity and heat) for this system is more than $68 \%$. Moreover, the energy supplied and exergy efficiency derived from the proposed cycle are stable versus changes in ambient temperatures. Besides, the effect of increasing the current density on the cell voltage and the total exergy destruction was considered. Also, the new approaches of the exergoeconomics and exergoenvironmental analysis are implemented in this system. The results show that the hybrid system can decrease the exergy destruction costs more than $16 \%$, and the environmental footprint of the system more than $23.4 \%$.
\end{abstract}

Keywords: Molten Carbonate Fuel Cell; MCFC; Turbo Expander; hybrid Steam Turbine; Exergy Efficiency.

(C) 2020 by the authors. This article is an open-access article distributed under the terms and conditions of the Creative Commons Attribution (CC BY) license (https://creativecommons.org/licenses/by/4.0/).

\section{Introduction}

Standard attention is focused on reducing greenhouse gases and other pollutants in the atmosphere by developing appropriate technologies to efficiently convert conventional and renewable resources to meet the growing energy demand. They are very energy-efficient devices. There are two types of high-temperature fuel cells: solid oxide fuel cell (SOFC) and molten carbonate fuel cell (MCFC) with operating temperatures between 600 and $800{ }^{\circ} \mathrm{C}[1]$. High-temperature fuel cell hybrid systems coupled with the gas turbine cycle can be an alternative approach to supply the fuel needed to generate electricity from a sustainable perspective. Besides, the MCFC generator can be synchronously combined with a gas turbine (GT) engine, as the MCFC exhaust gas temperature is generally high. Therefore, different types of integration of high-temperature fuel cells (SOFCs, MCFCs) and conventional generators with CHP systems have been proposed and implemented [2]. Numerous studies on MCFCs show that the integration of MCFC with gas turbine systems to generate electricity increases the efficiency and overall performance of the hybrid system [3].

Some of these related studies are presented in this section. Leto et al. [2]. Similar to the MCFC hybrid system combined with a small turbine, a sensitivity analysis was performed by 
changing the main parameters of the work. They have shown that this system can achieve $60 \%$ and $70 \%$, respectively, of full and efficient electricity. Imam and Dincer carried out active and dynamic analyzes of the MCFC-GT system and generally obtained energy and exergy efficiencies at $42.9 \%$ and $37.75 \%$, respectively [3]. Rashidi and others. Conducted a similar study on the MCFC gas turbine system and achieved overall energy efficiency of $57.4 \%$, the exergy efficiency of $56.2 \%$, low cycle energy efficiency of $24.7 \%$, and cumulative exergy efficiency of $43.4 \%$ [2]. Chacartegui et al. MCFC have a STIG cycle that operates under ambient pressure. Their study showed up to $69 \%$ effectiveness[4], done by Haseli et al., to investigate the performance of the SOFC-GT integrated power generation system. External energy and exergy efficiency were calculated at 60.6 and $57.9 \%$, respectively[5]. In other research, it was noted that the MCFC with an efficiency of $46.4 \%$ was able to integrate with the steam generation system to achieve an approximate total efficiency of $70 \%$ [1]. Truth Moghani et al. introduced the multi-objective optimization of the $200 \mathrm{~kW}$ MCFC-GT hybrid system [2]. Their work represents a total operating efficiency of $51.7 \%$ for this system. Although much work has been done on modeling and optimization of MCFC-based hybrid plants, no comprehensive thermal and environmental studies have been performed [3]. Applying the second law of thermodynamics to the concept of external energy while studying the general function of a plant, it is essential to know the number of losses in the system [2]. Besides, it is believed that energy-based thermodynamic analysis leads to more sustainable development [5]. By investigating this research gap, a new comprehensive thermodynamic model for the MCFC hybrid turbine plant is first developed, and then the system behavior is evaluated from a dynamic perspective [6]. A parametric study has also been conducted to investigate the effect of different operating parameters on system efficiency and energy degradation. Besides, based on the greenhouse gas emission perspective, the environmental aspects of the combined cycle presented in this paper are examined [7].

\section{Materials and Methods}

\subsection{Model assumptions.}

The compact MCFC, working above the MCFC to convert natural gas to $\mathrm{H}_{2}$, works with an external steam modifier. Before feeding to recover the MCFC cathode temperature, natural gas is heated in a heat exchanger using a steam reforming hot exhaust stream. The steam required for the regeneration reaction in the heat exchanger is generated by the hot current flowing out of the modifier and cathode in the MCFC and is used in combustion in the MCFC direction, where the remaining fuel is burned in the anode exhaust stream. The chimney gas produced from the anode is fed to the modifier, which supplies the heat needed for the heat reactions occurring inside the steam generator. During the process, carbon dioxide is concentrated at the MCFC anode. Therefore, the anode exhaust stream is high in carbon dioxide but also contains much steam. The humidity separator at the bottom of the MCFC is used to enrich the carbon dioxide anode exodus stream with some vapor condensation therein. The heat-humidity separator, extracted from the anode exhaust stream, gives a stream of water with recycled, cold water. The heat of this recycled hot water is then absorbed for other purposes, such as co-generation in a heat sink. Then compress the hot exhaust gases from the MCFC cathode into the turbo extension to generate electricity. The HRSG generator creates steam. This steam expands on the steam turbine, which drives the generator. The water vapor then condenses into the condenser. The cooling water circuit is powered by a sink and a cooling 
water pump. Condensed water from the condenser is pumped to the deaerator by the condenser pump, where it is extracted from the turbine using steam extraction. The feedwater is then pumped to the HRSG by the feed pump.

Material selection is essential for heat transfer in fuel cell systems with cooling problems. It can be seen that if the system is a mobile electrolyte mode, cooling studies are carried out about electrolyte circulation. It is essential to transfer heat in fuel cell systems with cooling problems and material selection. It can be seen that if the system is a moving electrolyte mode, the cooling studies relate to the circulation of the electrolyte. So, according to the rate of heat production in electrochemical reactions and materials chosen as electrodes and walls (which transport part of the produced heat) to the environment), the rotation of the electrolyte can be set One way or another to remove waste heat from the system. Moreover, the system performance temperature must be kept constant in the ideal amount $[15,16]$. Conversion equations can apply to different parts or the entire system [17].

Using the Cycle-Tempo program, the development and numerical simulation of the proposed hybrid system are performed [4]. All elements of this hybrid system are simulated (i.e., gas turbine, compressor, MCFC unit, heat exchanger, etc.). The following general assumptions are made for all devices [6]:

- The device operates in a steady-state [7].

- Heat exchangers work in the opposite direction of the current.

- The operation is steady [3].

- Restorative reactions occur at a constant temperature

For the first case, simulate this hybrid system by maintaining the mean current density and surface area of MCFC fixed cells at 1500 amps and $750 \mathrm{~m}^{3}$, respectively [1]. The composition of the natural gas used in the proposed hybrid cycle is shown in Table 1 [2].

Table 1. Composition of natural gas $[5,6]$.

\begin{tabular}{l|l} 
Component & Mole (\%) \\
\hline $\mathbf{C}_{2} \mathbf{H}_{\mathbf{6}}$ & 2.87 \\
\hline $\mathbf{C}_{3} \mathbf{H}_{\mathbf{8}}$ & 0.38 \\
\hline $\mathbf{C}_{\mathbf{4}} \mathbf{H}_{\mathbf{1 0}}$ & 0.15 \\
\hline $\mathbf{C}_{5} \mathbf{H}_{\mathbf{1 2}}$ & 0.04 \\
\hline $\mathbf{C}_{6} \mathbf{H}_{\mathbf{1 4}}$ & 0.05 \\
\hline $\mathbf{C H}_{\mathbf{4}}$ & 81.29 \\
\hline $\mathbf{C O}_{\mathbf{2}}$ & 0.89 \\
\hline $\mathbf{N}_{\mathbf{2}}$ & 14.32 \\
\hline $\mathbf{O}_{2}$ & 0.01 \\
\hline $\mathbf{L H V}(\mathbf{k J} / \mathbf{k g})$ & 37998.9
\end{tabular}

Additionally, in Table 2, input parameters to the MCFC section are shown, while input parameters to the turboexpander and steam turbine sections are shown in Table 3 [8].

Table 2. Input parameters of externally reformed MCFC unit.

\begin{tabular}{l|l} 
Parameter & Value (unit) \\
\hline Fuel utilization factor & 0.71 \\
\hline MCFC Reaction pressure & $8($ bar $)$ \\
\hline MCFC Reaction temperature & $650\left({ }^{\circ} \mathrm{C}\right)$ \\
\hline Stack area & $750(\mathrm{~m} 2)$ \\
\hline Cell resistance & $6.089 \times 10-5(\Omega)$ \\
\hline DC/AC conversion efficiency & 0.96 \\
\hline Anode and cathode inlet temperature & $600\left({ }^{\circ} \mathrm{C}\right)$ \\
\hline Steam reformer reaction pressure & $8($ bar $)$ \\
\hline Steam reformer reaction temperature & $800\left({ }^{\circ} \mathrm{C}\right)$
\end{tabular}


Table 3. Input parameters of turbo expander and steam turbine sections.

\begin{tabular}{l|l} 
Parameter & Value (unit) \\
\hline Turbo expander isentropic efficiency & 0.75 \\
\hline The expansion ratio of the turboexpander & 6 \\
\hline Generator efficiency of TE & 0.95 \\
\hline Steam turbine isentropic efficiency & 0.8 \\
\hline Outlet pressure of ST feedwater pump & 80 (bar) \\
\hline Steam drum circulation ratio & 4
\end{tabular}

\subsection{Energetic model.}

The MCFC unit used in this hybrid system is externally fixed [4]. The modifier is used to convert natural gas into a hydrogen-rich current located at the top of the fuel cell system [7]. The steam used in the repair work and the heat needed to react obtained from the anode port, which is burned before entering the repair work [8]. The MCFC model is used to calculate fuel cell performance as a function of parameters controlled by fuel cell operators. These control parameters include total fuel consumption and current density [5]. Fuel consumption is the degree to which fuel enters the cell. General specifications This form is available from MCFC: This model may be suitable for stacked plate cells and suitable cells [1]. The model is isothermal, namely the chemical equilibrium calculated in the region of the active cell and the current density based on the mean cell temperature [3]. The MCFC stack is composed of several cells connected to a chain with the same function. Operation in a similar fuel cell [9]:

$$
\emptyset_{m, a, i n}+\emptyset_{m, c, i n}-\emptyset_{m, a, o u t}-\emptyset_{m, c, o u t}=0
$$

The equation that models the mass exchange between cathode and anode is [4]:

$$
\emptyset_{m, a, i n}-\emptyset_{m, a, o u t}=-\emptyset_{m, c-a}
$$

All processes are assumed to occur at constant temperature and pressure (PCL and TCL), which is the average cell pressure and temperature. To fully convert all fuel components into fuel cells, the flow through the fuel is as follows[3]:

$$
I_{F}=\frac{\emptyset_{m, a, i n}}{M_{m o l, a}} *\left(y_{H_{2}}^{0}+y_{C O}^{0}+y_{C H_{2}}^{0}\right) * 2 F
$$

Where the concentration at the input and molecular complex of sodium gas is Mmol. Only a fraction of the fuel in the fuel cell changes [64]. If the ratio between the actual conversion and the maximum with the UF surface is used, the cell is given as the mainstream [1]:

$$
I=I_{F} * U_{F}
$$

Total mass flow $\mathrm{O}_{2}$ from cathode to anode is model by [1]:

$$
\emptyset_{O_{2}, c-a}=M_{m o l, O_{2}} * \frac{I}{4 F}
$$

$\mathrm{CO}_{2}$ transferred from the cathode to the anode is described by [2]:

$$
\emptyset_{\mathrm{CO}_{2}, \mathrm{C}-\mathrm{a}}=\mathrm{M}_{\mathrm{mol}, \mathrm{CO}_{2}} * \frac{\mathrm{I}}{2 \mathrm{~F}}
$$

The cathode output configuration is now calculated for the equilibrium cathode components. Likewise, the amount of $\mathrm{H}_{2}$ and $\mathrm{CO}$ converted to the cellular area is calculated by the "I" current [2]. Here is a one-dimensional model, that is, temperature, pressure, and compounds that appear at a fixed cross-section, and that is the direction of the fuel cell. The cell, cell voltage, reverse voltage, or non-alternating voltage is the same "Er" for any simple operation inside the fuel and is given as: [3]: 


$$
E_{r}=E_{T}^{0}+\frac{R T_{\text {cell }}}{2 F} \ln \left(\frac{\left(y_{O_{2}, c}^{\frac{1}{2}} \cdot y_{\mathrm{H}_{2}, a}^{1} \cdot y_{\mathrm{CO}_{2}, \mathrm{c}}^{1}\right)}{y_{\mathrm{H}_{2} \mathrm{O}, \mathrm{a}}^{1} \cdot y_{\mathrm{CO}_{2}, a}^{1}} * P_{\text {cell }}^{\frac{1}{2}}\right)
$$

There, the standard for hydrogen is a high voltage, which depends only on temperature, and the Gibbs energy " $\Delta G$ " is calculated as [70]:

$$
E_{T}^{0}=+\frac{\Delta G_{T}^{0}}{2 F}
$$

The processes in the cell are irreversible, and hence the cell voltage is smaller than the inverse voltage ' $V x$.' Here is the voltage drop between the reverse voltage and the actual voltage loss $\Delta \mathrm{Vx}$ as [2]:

$$
V_{x}=E_{r}-\Delta V_{x}
$$

The model assumes that the voltage loss at the electrode surface is negligible in the $\mathrm{x}$ direction [9]. This means that the cell voltage is constant over the fuel cell. Hence, the total voltage is [1]:

$$
V=E_{r}-\Delta V_{x}
$$

Voltage loss can be considered as the driving force of reaction in the fuel cell and, therefore, the current density [74]. Consequently, it can be assumed that the current frequency is proportional to the voltage drop. By analogy with Ohm's law, resistance is shown to be proportional to cellular resistance equivalent to "Req." For $\mathrm{x}$, the current density is equal to [7]:

$$
i_{x}=\frac{\Delta V_{x}}{R_{e q}}
$$

Finally, the rate with which $\mathrm{H}_{2}$ is converted in a cross-section $\mathrm{x}$ can be estimated from the current density as [3]:

$$
\frac{\partial n_{H_{a}}}{\partial x}=\frac{i_{x}}{2 F}
$$

The concentration changes of the components are calculated using the above equations, the mole equilibrium for the components, and the reaction level for the change reaction [3]. Based on the given equations, the voltage and current density at a cross-section are calculated using numerical methods. The output power of the fuel cell stack is as follows [2]:

$$
P_{e}=V * I * \eta_{D C-A C}
$$

Roger and Miho's method of modeling was considered a turbo extender [8]. This method, shown below, is for a specific heat factor $(\mathrm{Cp})$ and an equilateral $(\gamma)$ index in the whole process or parts of the process. These data are used to calculate variable efficiency. However, the study provides a provision to provide variable efficacy by turbine properties from previous studies [9]. Straight stretch lines are considered in the Mollier diagram between entry and exit conditions to calculate the enthalpy specified in extraction processes. According to the description above, the turbo extender temperature was estimated using equation 14 [10]:

$$
T_{4}=T_{3}-T_{3} \cdot \eta_{t} \cdot\left(1-\frac{1}{R_{t}}\right)^{\frac{\gamma-1}{\gamma}}
$$

Where $\eta_{t}$ is the isentropic efficiency of the turboexpander, and $R_{t}$ is the expansion ratio. Additionally, the work of the turbine is calculated by Eq. (15) as follows [9]:

$$
W_{t}=C_{p} \cdot\left(T_{3}-T_{4}\right)
$$


The steam turbine bottom cycle is designed based on the Rankin cycle methodology[11]. In this section, the average temperature at which heat is provided is below the maximum temperature, so efficiency is less than the Carnot cycle that operates between the same maximum and minimum temperatures $[10,11]$. For modeling, this cycle, the primary energy absorbed by the boiler, the energy produced by the generator, the electricity consumption of the pumps, and the net energy supplied are indicated [9, 12]. It should be noted that the consumption of electric pumps is considered an auxiliary energy consumer, which, when subtracted from the total electricity generated is estimated net energy supplied [13]. The input and output functions have been defined to examine the effectiveness of the Rankin cycle so that thermal efficiency can be written as follows $[12,13]$ :

$$
\eta_{\text {thermal } S T}=\left(W_{\text {out }}-W_{\text {in }}\right) / Q_{-} \text {in }
$$

Where, $\mathrm{W}_{\text {out }}$ and $\mathrm{W}_{\text {in }}$ are generated power and auxiliary work, respectively. Also, $\mathrm{Q}_{\text {in }}$ is the input fuel heat to the cycle $[12,13]$.

In the humidifier, the inlet gas is cooled by a coolant flowing in the opposite direction, thereby condensing the water vapor [14]. The capacitors are collected and discharged through a separate tube. Three mass equations (mass equilibrium, the second equation for the cooling medium, the equation for the number of separated capacitors, namely the specific mass equation) and energy equation for cooling are used in the system modeling to calculate the buoyancy mass $[1,7]$. In the proposed cycle, greater use of thermal exergy and waste reduction in the plant are considered to increase efficiency [6, 10]. As observed in Eq. (17) The whole cycle efficiency is obtained from the sum of the electrical and thermal efficiency of the system. The electrical efficiency of the system is obtained from MCFC, Turbo Expansion, and Steam Turbine Electrical Performance using General Eq. (18) [13]. The overall performance of the system is calculated by Eq. (19) and is shown in Table 4 [2].

$$
\begin{aligned}
& \eta_{\text {Total }}=\eta_{\text {electrical }}+\eta_{\text {heat }} \\
& \eta_{\text {electrical }}=\frac{W_{\text {net }}}{L H V_{\text {fuel }} * \xi_{\text {fuel }}}
\end{aligned}
$$

\begin{tabular}{|c|c|c|}
\hline Element & Exergy Efficiency & Equation \\
\hline Functional efficiency & $\eta_{E x, f}=\frac{\sum E x_{\text {product }}}{\sum E x_{\text {source }}}$ & 19 \\
\hline Electrical efficiency & $\eta_{\text {Ex,ele }}=\frac{\sum E x_{\text {ele,out }}-\sum E x_{\text {ele, in }}}{\sum E x_{\text {fuel }}}$ & 20 \\
\hline Exergy efficiency & $\eta_{E x, \text { total }}=\frac{\sum E x_{\text {ele }, \text { out }}+\sum E x_{\text {heat }, \text { out }}-\sum P_{\text {ele }, \text { in }}}{\sum E x_{\text {fuel }}}$ & 21 \\
\hline $\begin{array}{l}\text { Exergy efficiency Fuel } \\
\text { cell }\end{array}$ & $\eta_{E x, f(c e l l)}=\frac{E_{\text {ele }}}{\left(E x_{\text {fuel,in }}-E x_{\text {fuel,out }}\right)+E x_{\text {ox }, \text { in }}-E_{\text {ox,out }}}$ & 22 \\
\hline $\begin{array}{l}\text { Exergy efficiency } \\
\text { turbine }\end{array}$ & $\eta_{E x, f(\text { turbine })}=\frac{E_{\text {shaft }}}{E x_{\text {in }}-\sum E x_{\text {out }}}$ & 23 \\
\hline $\begin{array}{l}\text { Exergy efficiency } \\
\text { Steam reformer }\end{array}$ & $\begin{array}{l}\eta_{\text {Ex,f(reformer })} \\
=\frac{E x_{\text {productgas }}^{\text {ch }}-E x_{\text {steam }}^{\text {ch }}-E x_{\text {feed }}^{c h}}{\left(E x_{\text {fluegas }, \text { in }}^{\text {tm }}-E x_{\text {flue gas }, \text { out }}^{\text {tm }}\right)-\left(E x_{\text {product gas }}^{\text {tm }}-E x_{\text {steam }}^{\text {tm }}-E x_{\text {feed }}^{t m}\right)}\end{array}$ & 24 \\
\hline $\begin{array}{l}\text { Exergy efficiency heat } \\
\text { exchanger }\end{array}$ & $\eta_{E x, f(\text { Heat exchanger })}=\frac{E x_{p, \text { out }}-E x_{p, \text { in }}}{E x_{s, \text { out }}-E x_{s, \text { in }}}$ & 25 \\
\hline $\begin{array}{l}\text { Exergy efficiency } \\
\text { drum }\end{array}$ & $\eta_{E x, f(\text { drum })}=\frac{E x_{\text {Steam }, \text { out }}-E x_{\text {steam }, \text { in }}}{E x_{\text {evaporator,out }}-E x_{\text {evaporator }, \text { in }}}$ & 26 \\
\hline $\begin{array}{l}\text { Exergy efficiency } \\
\text { combustion chamber }\end{array}$ & $\eta_{E x, f(\text { Combustion chamber })}=\frac{E x_{\text {flue gas }}^{t m}-E x_{\text {fuel }}^{t m}-E x_{o x}^{t m}}{E x_{\text {fuel }}^{c h}+E x_{o c}^{c h}-E x_{\text {flue gas }}^{c h}}$ & 27 \\
\hline $\begin{array}{l}\text { Exergy efficiency } \\
\text { compressor, pump }\end{array}$ & $\eta_{E x, f(\text { Compressor }, \text { pump })}=\frac{E x_{\text {out }}-E x_{\text {in }}}{E x_{\text {shaft }}}$ & 28 \\
\hline
\end{tabular}

Table 4. Exergy equations in cycle simulation. 


\subsection{Exergoenvironmental and exergoeconomics.}

The conventional environmental method developed by Tsatsaronis et al. From 2008 [1, 2 ,4] forms the basic structure of the currently proposed method that can consider the complexity of the fitting of a system. The method and formulation of the method are well presented in their studies. Similarly in the exergy cost theory to evaluate the exergy cost of flows, the extrinsic method presents the environmental charge per unit energy exergy in a system in solving a system of equations consisting of the principal environmental diffusion (or effects) equilibrium for each unit within the system And some auxiliary equations for allocating loads to more than one output per unit. [7] The solution of these equations may provide a wasteto-cost ratio of Torres, Sidney, and Anadolu. The specific appropriateness of this method for accounting for the environmental responsibility is the transfer of fertile contamination burden between service providers (or feeders) and consumers [5-7].

As presented in [9], the main equations reflecting the equilibrium environmental charge (B $(k t o n / y r)$ ) in kth unit with Y (kton / yr) emission rate are as follows:

$$
B_{k, \text { out }}=B_{k, \text { in }}+Y_{k}
$$

In the above equation, each one of the total environmental loads' inputs to (output of) the unit is the summation of 1 input (n output) streams loads. Also, each stream's environmental load is the product of exergy amount $(E(k W))$ in environmental load per unit exergy $\left(b_{i}(\right.$ $k$ ton. $\left.y r^{-1} . k W^{-1}\right)$ ) of the streams.

$$
B_{k, \text { in (out) }}=\sum_{i=1, j=1}^{I(n)} b_{i(j), k, \text { im (out })} E_{i(j), k, \text { im (out })}
$$

The term of $Y_{k}$ represents the life cycle environmental impacts depending on the scope of the analysis. In our case of study, the PM10 emissions within the system borders are being studied. Hence, the construction or waste dismantling emissions, as well as other environmental discharges, are not to be studied.

It is worth mentioning here that in the advanced environmental approach, the effects/emissions of avoidable and unavoidable greenhouse gases have been identified, and the above equations have been written for avoidable parts $[12,16]$. However, as discussed in $[14$, 17], thanks to well-developed control techniques, it is almost impossible to prevent the release of PM10 kidneys. Therefore the differentiation made in the advanced method is not necessary. The auxiliary equations of the outer environment necessary to solve the system of equations presented in (1) are Equations F: The specific environmental charge for the inlet and outflows is unchanged from a fixed unit. Equations P: For a flow coming out of a component, the exterior environmental charge has a value. Alongside these two rules, the per-unit loads of inlet currents through the system boundaries are assumed to be zero before experiencing any conversion. This is due to the aim of the study in which the emission of gases within the system contributing to local pollution is of importance and is to be managed while the emission of greenhouse gases outside the boundaries before the delivery of feeds is of importance in the integrated environmental definition systems which are not allowed for integrated Management.

The method for external economic analysis is similar to environmental analysis. It combines an exergy analysis of the energy conversion system and then an economic analysis based on the Total Income Requirements (TRR) method, which covers the entire life cycle of the energy conversion system [3, 18]. Initially, the total capital investment is calculated. Then, based on the assumptions of economic, financial, operational, and market input parameters, the total annual revenue needed is calculated. This TRR represents the cost of producing system 
products and offsets all costs incurred each year of the project's economic life to guarantee an industrial plant. After that, the annual variable costs of the product related to investment, operation, maintenance, fueling, and other costs (cost categories) are leveled. These equipment are converted into a series of fixed payments equivalent to the annuity. Next, by calculating the specific cost rate of each material and energy flow, the costs are assigned to the respective exergy flows. Since the external economic analysis is well established, only the formulas of analogy with those used for environmental analysis are presented in Table 5.

Table 5. Equations for exergoeconomic and exergoenvironmental assessments.

\begin{tabular}{|c|c|c|c|}
\hline Exergoeconomics & & Exergoenvironmental & \\
\hline $\begin{array}{l}\begin{array}{l}\text { Exergy stream cost } \\
\text { rate }\end{array} \\
\end{array}$ & $C_{j}^{\cdot}=c_{j} * E_{j}^{\cdot}$ & $\begin{array}{l}\text { Exergoenvironmental } \\
\text { stream impact rate: }\end{array}$ & $B^{\cdot} j=b j \cdot E^{\cdot} j$ \\
\hline $\begin{array}{l}\text { Component cost } \\
\text { balance }\end{array}$ & $\sum C \cdot j, k$, in $+Z k=\Sigma C \cdot j, k$, out & $\begin{array}{l}\text { Component } \\
\text { environmental impact } \\
\text { balance }\end{array}$ & $\sum B^{\prime} j, k$, in $+Y^{\prime} k=\sum B^{\prime} j, k$, out \\
\hline $\begin{array}{l}\text { Component-related } \\
\text { cost rate }\end{array}$ & $Z k=Z_{k}^{C L}+Z_{k}^{O M}$ & $\begin{array}{l}\text { Component-related } \\
\text { environmental impact rate }\end{array}$ & $Y_{k}=Y_{K}^{C O}+Y_{K}^{O M} \cdot+Y_{K}^{D I}$ \\
\hline $\begin{array}{l}\text { The component } \\
\text { relative cost difference }\end{array}$ & $r_{k}=\frac{C_{P, k}+C_{F, k}}{C_{F, k}}$ & $\begin{array}{lr}\text { Component } & \text { relative } \\
\text { environmental } & \text { impact } \\
\text { difference } & \\
\end{array}$ & $r_{b, k}=\frac{b_{P, k}-b_{F, k}}{b_{F, k}}$ \\
\hline $\begin{array}{l}\text { Component } \\
\text { exergoeconomic } \\
\text { factor }\end{array}$ & $f_{k}=\frac{Z_{k}}{Z_{k}+C_{D, k}}$ & $\begin{array}{l}\text { Component } \\
\text { exergoenvironmental } \\
\text { factor }\end{array}$ & $f_{b, k}=\frac{Y_{k}}{Y_{k}+B_{D, k}}$ \\
\hline
\end{tabular}

\section{Results and Discussion}

The simulation of this hybrid system enables the evaluation of mass, energy production, energy efficiency, and energy values in different components of the system. For this system, it was noted that pure electrical energy efficiency was achieved at $71.0 \%$ when $2.59 \mathrm{steam} / \mathrm{fuel}$ was maintained for the repairman, and $71 \%$ at MCFC fuel consumption. This is the primary function of the system. At the MCFC cathode, the cathode recycles, and steam reformer exhaust is fed to the cathode inlet with fresh air. Besides, the output stream of recycled anode after $\mathrm{CO}_{2}$ enrichment in the humidifier is supplied to the modifier combustion at $460{ }^{\circ} \mathrm{C}$. Both the anode and the cathode release MCFC gases at $700^{\circ} \mathrm{C}$. The electric power provided by the turbo developer is about $218 \mathrm{~kW}$, while the MCFC supplies about $948 \mathrm{~kW}$. Hot steam is generated in the HRSG. This steam is used to generate approximately $55.5 \mathrm{~kW}$ in the steam turbine cycle using an expanded exhaust stream. For this type of external energy analysis, it is essential to have the amount of energy available for process flow and energy loss in the devices as well as the external energy factors of the devices. Emergency analysis of the combined cycle was performed based on the equations shown in Table 6 [1, 2, 16, 19-22].

Table 6. Results of simulation for the proposed hybrid system in the base case.

\begin{tabular}{l|l} 
Parameter & Value (unit) \\
\hline Fuel flow rate & $0.043(\mathrm{~kg} / \mathrm{s})$ \\
\hline Turbo expander inlet temperature & $973.15(\mathrm{~K})$ \\
\hline MCFC delivered power & $940.97(\mathrm{~kW})$ \\
\hline Turbo expander delivered power & $218.7(\mathrm{~kW})$ \\
\hline Steam turbine delivered power & $55.54(\mathrm{~kW})$ \\
\hline Auxiliary power consumption & $97.20(\mathrm{~kW})$ \\
\hline Net electrical power output & $1125.05(\mathrm{~kW})$ \\
\hline Delivered heat & $59.34(\mathrm{~kW})$ \\
\hline Gross electrical exergy efficiency & $71.00(\%)$ \\
\hline Net electrical exergy efficiency & $65.35(\%)$ \\
\hline Total exergy efficiency & $68.74(\%)$
\end{tabular}


Figure 1 shows the overall variance of plant energy efficiency with an increase in steam/fuel consumption of $2.59 \%$ for the boiler.



Figure 1. diversion of the total exergy efficiency of the proposed hybrid system with steam/fuel ration of $2.59 \%$ for the available range of fuel utilization.

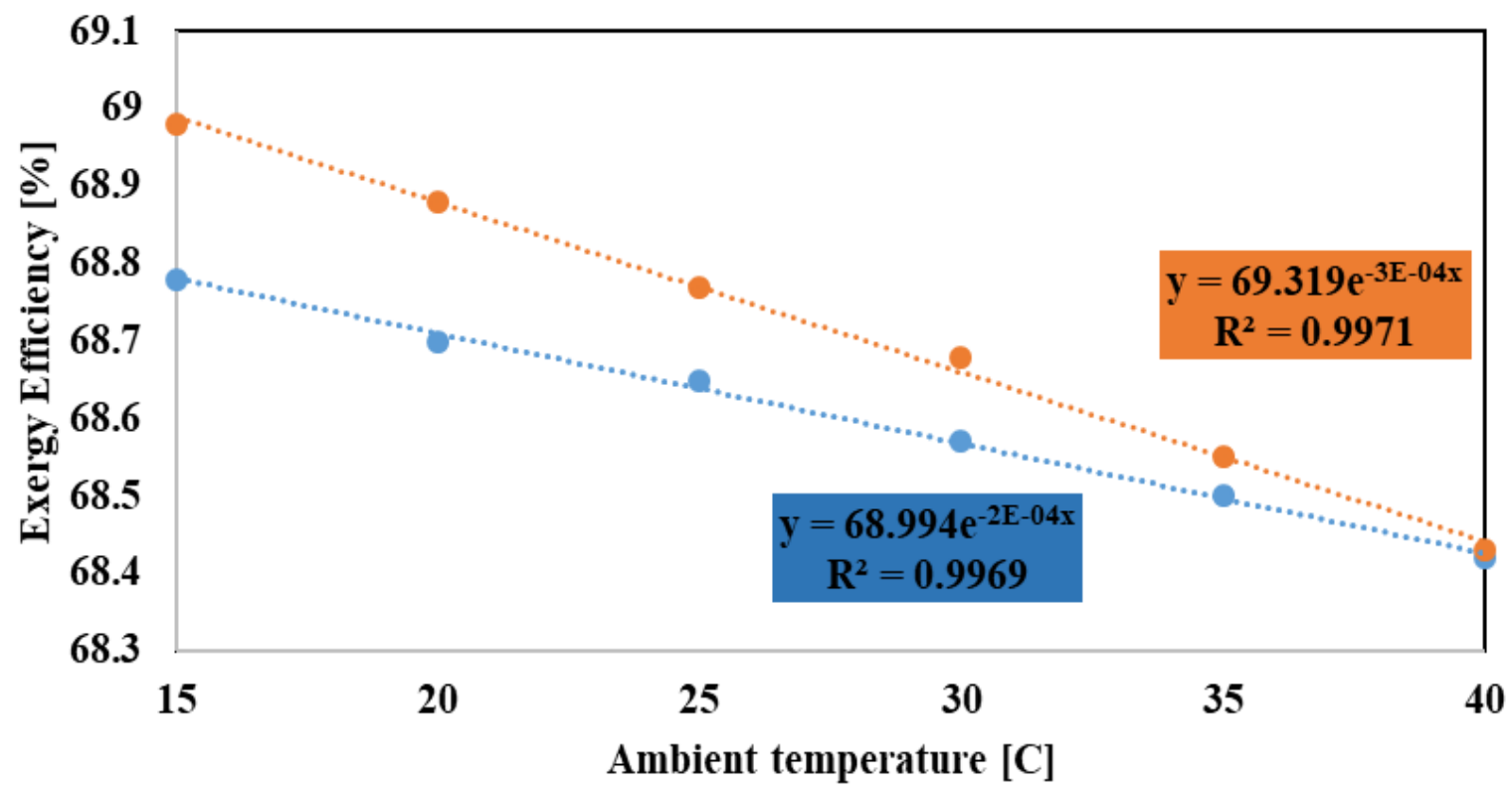

- Exergy efficiency

- Net Delivered power

Figure 2. Variation of total exergy efficiency and net delivered the power of the proposed hybrid system for ambient temperature and relative

The optimal range of use coefficients for this system is $59-71 \%$, thus achieving maximum overall energy efficiency of $68.74 \%$ for fuel consumption of $71 \%$. The performance of the leading case of the hybrid system is shown in Table 6. Based on the presented calculations, the proposed cycle is more efficient than previous studies. The main results of previous studies are presented in the introduction. Usually, compare the results of different researches using a quantitative approach. One of the benefits of the recommended cycle, as shown in Figure 2, is its low sensitivity to ambient temperature changes. As the ambient 
temperature increases for each degree $\mathrm{C}$, the output power is reduced by about $0.02 \%$ compared to gas turbines [9]. Therefore, this cycle can be an excellent alternative to conventional hybrid systems in the tropics, where the energy provided for complex cycles shows a significant decrease. This cycle is designed for Tehran and Iran climates, so the average mean ambient temperature and relative humidity in Tehran are shown in Table 7 . The operating temperature of the cell is $650^{\circ} \mathrm{C}$.

Increasing the current density leads to a decrease in operating voltage due to the loss of power, which can also be deduced from equation (11).

As a result, higher current density results in a higher rate of loss of external cell fuel, which contributes the most to the total energy depletion at the plant, thereby worsening the overall energy efficiency of the combined cycle. According to Table 7, the use of a turbine and steam turbine with heat recovery in this combined cycle has increased the energy efficiency compared to previous studies. Significant energy losses are incurred, such as combustion and repair equipment and heat exchangers. For some devices, such as pumps and compressors, there is little mention of the additional energy consumption losses[11, 20].

Table 7. Averages of ambient temperature and relative humidity in Tehran, Iran

\begin{tabular}{l|l} 
Ambient Temperature $\left({ }^{\circ} \mathbf{C}\right)$ & Relative humidity (\%) \\
\hline 15 & 30 \\
\hline 20 & 28 \\
\hline 25 & 22 \\
\hline 30 & 19 \\
\hline 35 & 17 \\
\hline 40 & 15
\end{tabular}



Figure 3. Effect of current density variations on exergetic efficiency.

The heat from the heat sink is taken into account in the humidifier. The inlet and outlet temperatures of this unit are 80 and $60^{\circ} \mathrm{C}$, respectively. Energy efficiency shows the thermodynamic importance of heat generated [14]. Since the thermal energy is temperaturedependent, and the finite temperature is always lower than the energy value, the thermal energy efficiency of the power plants is usually lower than the similar thermal temperature (See table 8). This difference is especially marked by the temperature of the heat produced [15] (see figure $3)$. 
Table 8. Calculated exergy efficiencies of the main elements of the proposed cycle.

\begin{tabular}{l|c|c|c} 
Apparatus (No.) & Exergy Efficiency (\%) & $\mathbf{E}(\boldsymbol{\%})$ & $\mathbf{F}(\boldsymbol{\%})$ \\
\hline Turbo Expander (16) & 87.43 & 83.6736 & 31.6416 \\
\hline Steam Turbine (38) & 80.40 & 78.9504 & 4.1376 \\
\hline MCFC (11) & 93.04 & 91.7376 & 30.7584 \\
\hline Compressor (7) & 57.97 & 68.1984 & 24.6336 \\
\hline Compressor (15) & 76.80 & 77.5968 & 18.7968 \\
\hline Compressor (26) & 76.50 & 87.1296 & 66.5472 \\
\hline Reformer (9) & 80.48 & 70.4064 & 35.952 \\
\hline Pump (4) & 44.43 & 54.864 & 94.5024 \\
\hline Pump (8) & 55.10 & 43.1904 & 3.888 \\
\hline Pump (40) & 45.37 & 92.8992 & 8.064 \\
\hline Pump (42) & 49.40 & 76.656 & 17.9616 \\
\hline Pump (44) & 55.54 & 64.6656 & 4.8768 \\
\hline Pump (238) & 86.43 & 11.1072 & 0.0864 \\
\hline Combustion chamber (10) & 76.10 & 98.7656 & 28.47744 \\
\hline Heat Exchanger (1) & 67.96 & 75.30624 & 3.72384 \\
\hline Heat Exchanger (2) & 66.87 & 71.05536 & 27.68256 \\
\hline Heat Exchanger (3) & 80.46 & 82.56384 & 22.17024 \\
\hline Heat Exchanger (17) & & 61.37856 & 16.91712 \\
\hline Heat Exchanger (18) & 75.89 & 69.83712 & 59.89248 \\
\hline Heat Exchanger (19) & 64.37 & 78.41664 & 32.3568 \\
\hline Heat Exchanger (20) & 65.64 & 63.36576 & 85.05216 \\
\hline Heat Exchanger (233) & 66.11 & 89.3776 & 3.4992 \\
\hline Heat Exchanger (235) & 66.47 & 83.60928 & 16.16544
\end{tabular}

\section{Conclusions}

In this study, a new hybrid system of MCFC-Turbo steam expansion steam turbines is proposed to achieve high power generation capacity in current MCFC cycles and at the reasonable overall energy efficiency of the plants. The following results can be obtained from this study: The maximum performance of an efficient power plant was $71.0 \%$ with steam to fuel ratio of 2.59 and $71 \%$ for fuel consumption. About $55.5 \mathrm{~kW}$ of electricity is generated by the plant when operating on the original. The total energy efficiency of the system (electricity and heat) is $68.74 \%$. An increase in MCFC fuel utilization rate (within range) indicates a significant increase in overall energy efficiency. At ambient temperature changes from 15 to 40 degrees Celsius, the energy produced is reduced by about $0.5 \%$, while being substantially higher in gas turbines or steam turbine cycles. An increase in the current density of the MCFC has reduced the electrical losses and the combined energy loss of the hybrid system.

\section{Funding}

This research received no external funding.

\section{Acknowledgments}

This research has no acknowledgment.

\section{Conflicts of Interest}

The authors declare no conflict of interest.

\section{References}

1. Norouzi, N.; Talebi, S. An overview on the green petroleum production. Chemical Review and Letters 2020 , 3, 38-52, https://dx.doi.org/10.22034/crl.2020.222515.1041. 
2. Norouzi, N.; Fani, M.; Ziarani, Z.K. The fall of oil Age:A scenario planning approach over the last peak oil of human history by 2040. Journal of Petroleum Science and Engineering 2020, 188, https://doi.org/10.1016/j.petrol.2019.106827.

3. Mirvakili, A.; Chahibakhsh, S.; Ebrahimzadehsarvestani, M.; Soroush, E.; Rahimpour, M.R.Modeling and assessment of novel configurations to enhance methanol production in industrial mega-methanol synthesis plant. Journal of the Taiwan Institute of Chemical Engineers 2019, 104, 40-53, https://doi.org/10.1016/j.jtice.2019.09.018.

4. Chen, K.; Yu, J.; Liu, B.; Si, C.; Ban, H.; Cai, W.; Li, C.; Li, Z.; Fujimoto, K. Simple strategy synthesizing stable $\mathrm{CuZnO} / \mathrm{SiO} 2$ methanol synthesis catalyst. Journal of Catalysis 2019, 372, 163-173, https://doi.org/10.1016/j.jcat.2019.02.035.

5. Norouzi, N.; Talebi, S. Exergy and Energy Analysis in Effective Utilization of Carbon Dioxide in the Gasto-Methanol Process. Iranian Journal of Hydrogen \& Fuel Cell 2020, 7.

6. Norouzi, N.; Talebi, S.; Shahbazi, A. An overview on the carbon capture technologies with an approach of green coal production study. Chemical Review and Letters 2020, 3, 65-78, https://doi.org/10.22034/crl.2020.224177.1043.

7. Norouzi, N.; Talebi, S.; Fani, M. Heat Pump Thermal Storage for Molton Salt in the Solar Technology. Mat Int 2020, 2, 0219-0230.

8. Fani, M.; Norouzi, N. Numerical Modeling of Thermal Energy Storage of CHPs in Porous Concrete. Mat Int 2020, 2, 0191-0204, https://doi.org/10.33263/Materials22.191204.

9. Norouzi, N.; Talebi, S.; Fani, M. Thermal Energy Storage for the Complex Energy Systems. Mat Int 2020, 2, 0175-0190, https://doi.org/10.33263/Materials22.175190.

10. Seyed Mahmoudi, S.M.; Sarabchi, N.; Yari, M.; Rosen, M.A. Exergy and Exergoeconomic Analyses of a Combined Power Producing System including a Proton Exchange Membrane Fuel Cell and an Organic Rankine Cycle. Sustainability 2019, 11, https://doi.org/10.3390/su11123264.

11. Arshad, A.; Ali, H.M.; Habib, A.; Bashir, M.A.; Jabbal, M.; Yan, Y. Energy and exergy analysis of fuel cells: A review. Thermal Science and Engineering Progress 2019, 9, 308-321, https://doi.org/10.1016/j.tsep.2018.12.008.

12. Wiranarongkorn, K.; Banerjee, A.; Deutschmann, O.; Arpornwichanop, A. Performance analysis and temperature gradient of solid oxide fuel cell stacks operated with bio-oil sorption-enhanced steam reforming. International Journal of Hydrogen Energy 2020, 45, 12108-12120, https://doi.org/10.1016/j.ijhydene.2020.02.120.

13. Ahmed, K.; Amiri, A.; O. Tadé, M. Simulation of Solid Oxide Fuel Cell Anode in Aspen HYSYS—A Study on the Effect of Reforming Activity on Distributed Performance Profiles, Carbon Formation, and Anode Oxidation Risk. Processes 2020, 8, https://doi.org/10.3390/pr8030268.

14. Tang, S.; Amiri, A.; Tadé, M.O. System Level Exergy Assessment of Strategies Deployed for Solid Oxide Fuel Cell Stack Temperature Regulation and Thermal Gradient Reduction. Industrial \& Engineering Chemistry Research 2019, 58, 2258-2267, https://doi.org/10.1021/acs.iecr.8b04142.

15. Behzadi, A.; Habibollahzade, A.; Zare, V.; Ashjaee, M. Multi-objective optimization of a hybrid biomassbased SOFC/GT/double effect absorption chiller/RO desalination system with $\mathrm{CO} 2$ recycle. Energy Conversion and Management 2019, 181, 302-318, https://doi.org/10.1016/j.enconman.2018.11.053.

16. Shayan, E.; Zare, V.; Mirzaee, I. On the use of different gasification agents in a biomass fueled SOFC by integrated gasifier: A comparative exergo-economic evaluation and optimization. Energy 2019, 171, 11261138, https://doi.org/10.1016/j.energy.2019.01.095.

17. Shayan E; Zare V; Mirzaee I. Exergoeconomic Analysis of an Integrated Steam Biomass Gasification System with a Solid Oxide Fuel Cell for Power and Freshwater Generations. Modares Mechanical Engineering 2020, 20, 553-564.

18. Yuksel, B.; Balli, O.; Gunerhan, H.; Hepbasli, A. Comparative Performance Metric Assessment of A Military Turbojet Engine Utilizing Hydrogen And Kerosene Fuels Through Advanced Exergy Analysis Method. Energies 2020, 13, https://doi.org/10.3390/en13051205.

19. Ghorbani, S.; Khoshgoftar Manesh, M.H. Conventional and Advanced Exergetic and Exergoeconomic Analysis of an IRSOFC-GT-ORC Hybrid System. Gas Processing Journal 2020, 8, 1-16, https://doi.org/10.22108/gpj.2019.119599.1067.

20. Sayin Kul, B.; Kahraman, A. Energy and Exergy Analyses of a Diesel Engine Fuelled with Biodiesel-Diesel Blends Containing 5\% Bioethanol. Entropy 2016, 18, https://doi.org/10.3390/e18110387.

21. Talebi, S.; Norouzi, N. Entropy and exergy analysis and optimization of the VVER nuclear power plant with a capacity of $1000 \mathrm{MW}$ using the firefly optimization algorithm. Nuclear Engineering and Technology 2020, https://doi.org/10.1016/j.net.2020.05.011.

22. Norouzi, N. 4E Analysis and design of a combined cycle with a geothermal condensing system in Iranian Moghan diesel power Plant. International Journal of Air-Conditioning and Refrigeration 2020, https://doi.org/10.1142/S2010132520500224. 